\title{
DEVELOPMENT OF MULTIFUNCTIONAL FORMULATIONS FOR INHIBITION OF WAXES AND ASPHALTENES DEPOSITION
}

\author{
${ }^{a}$ Palermo, L. C. M. ${ }^{1}$; ${ }^{\text {a }}$ Souza Jr, N. F.; ${ }^{a}$ Louzada, H. F.; ${ }^{b}$ Bezerra, M. C. M.; ${ }^{a}$ Ferreira, L. S.; ${ }^{a}$ Lucas, E. F. \\ ${ }^{\mathrm{a}}$ Federal University of Rio de Janeiro (UFRJ), Institute of Macromolecules (IMA), RJ, Brazil \\ ${ }^{\mathrm{b}}$ Cenpes/Petrobrás, Research Center Leopoldo Miguez de Mello, RJ, Brazil
}

\begin{abstract}
The development of formulations that solve at least two problems simultaneously (called multifunction or combo formulations) is very useful. In this study, different formulations were prepared in an attempt to find one that could act at the same time to inhibit deposition of waxes and asphaltenes. Formulations were prepared containing EVA 33 and one of the additives for asphaltenes dispersion (dodecylbenzenesulfonic acid, cardanol and two commercial products called INH1 and INH2), at various concentrations. The results showed that none of the asphaltenes stabilizers exhibited any influence on the performance of EVA33. Nevertheless, the EVA33 affected slightly the performance of the asphaltenes stabilizers. The formulations containing cardanol and EVA 33 performed better at inhibiting deposition of both asphaltenes and waxes than the other formulations did.
\end{abstract}

\section{KEYWORDS}

multifunctional formulations; organic deposition; precipitation onset; pour point; wax appearance temperature

\footnotetext{
${ }^{1}$ To whom all correspondence should be addressed.

Address: Federal University of Rio de Janeiro (UFRJ), Institute of Macromolecules (IMA), Laboratory of Macromolecules and Colloids for Petroleum Industry (LMCP), 21941598, Rio de Janeiro- Brazil CEP: 21941-598 | Telephone/Fax number: +55 21 2562-7033 | e-mail: luizpalermo@ima.ufri.br doi:10.5419/bjpg2013-0015
} 


\section{INTRODUCTION}

Crude oil is a complex mixture of hydrocarbons, which are divided into different groups, such as waxes, aromatics, naphthenes, resins and asphaltenes. Among these substances, waxes and asphaltenes stand out as the main causes of organic deposition (Embrey \& Larke, 2010; Lucas et al., 2009; Mansur et al., 2012; Vieira et al., 2010). Problems related to crystallization and deposition of heavy organic fractions during the production, transportation, and storage of crude oil can cause huge losses to the petroleum industry. These heavy organic fractions, such as waxes, resins and asphaltenes, can be found in petroleum in different quantities, forms and states. All of them can cause problems from the extraction to the refining stages (Araújo et al., 2008; Junior et al., 2007; Kane et al., 2003; Oliveira et al., 2007; Piroozan et al., 2010).

The deposition of the waxes present in crude oil results from the crystallization process which, in turn, is a consequence from the ordering of the paraffin chains favored by cooling. The crystallization process can be divided into three stages. The first is the nucleation, where the crystalline nuclei initially start to appear. In the next stage, the crystals grow, provided that the temperature of the system remains below the nucleation temperature. In the last stage, the crystals unite to form a three-dimensional wax network that impedes the oil flow (Hutter et al., 2004; Terry et al., 2003; Zhang et al., 2005). At this point, called the pour point (PP), the oil is highly viscous. The pour point is defined as the lowest temperature at which the oil will flow freely under the action of its own weight (Chen et al., 2010; Visintin et al., 2008). Various authors have mentioned the efficiency of polymers to inhibit deposition of waxes. These polymers have structures based on ethylene, acrylic and methacrylic esters with long alkyl groups, and phosphoric esters, among others (Aiyejina et al., 2011; Castro \& Vazquez, 2008; Gentili et al., 2005; Mansur et al., 2006; Marie et al., 2005; Silva et al., 2004; Soni et al., 2010, Vieira et al., 2012).

Asphaltenes are the petroleum components with the highest polarity and molar mass. They have great structural complexity due to their polycondensed aromatic rings, containing alkyl radicals of different sizes and functional groups formed by oxygen, nitrogen and sulfur, as well as heavy metals such as vanadium, nickel and iron (Honse et al., 2012; Mullis, 2007). Asphaltenes are defined as the petroleum fraction that are insoluble in $\mathrm{n}$-alkanes (n-pentane, $\mathrm{n}$-heptane etc.) and soluble in aromatic solvents (benzene and toluene) (Fan et al., 2010). They are found in crude oil as a stable colloidal suspension (Chouparova et al., 2004). However, during oil production, the suspension can become destabilized due to variations in pressure and temperature, changes in the oil's chemical composition, and field operations such as acid stimulation (Smith et al., 2008; Vargas et al., 2009; Juyal et al., 2010). Asphaltenes are deposited due to the aggregation of these molecules. Various studies have mentioned the use of amphiphilic molecules as asphaltenes dispersants, which contains acids groups and long alkyl chains, such as p-alkylphenols (Chang \& Fogler, 1994; Moreira et al., 1998). A recent study carried out by this group showed that polymers containing specific polar groups in their structure, such as sulfonic groups, act to stabilize asphaltene molecules (Lima et al., 2010).

The present study examined the performance of different formulations in an attempt to obtain a combo formulation that can, at the same time, inhibit the deposition of waxes and asphaltenes. Due to the similar solubility of waxes and asphaltenes deposition inhibitors, the development of a multifunctional formulation that mitigates both of these deposition problems is very attractive to the petroleum industry. For this purpose, various concentrations of dodecylbenzenesulfonic acid (DBSA), cardanol, and two commercial products (INH1 and INH2) were evaluated as asphaltenes dispersants. In turn, commercial ethylene-co-vinyl acetate copolymer containing a 33 wt.\% of vinyl acetate (EVA33), at various concentrations, was analyzed as a wax deposition inhibitor. Various formulations were prepared containing EVA33 and one of the additives with action on asphaltenes, at various concentrations. The development of multifunctional formulations that mitigate different problems during petroleum production has been gaining importance due to cost reductions and greater operational efficiency (Gonzales et al., 2012; Hernandez-Altamirano et al., 2012; Jackson, 2007; Mc Naughtan et al., 2004). Another important advantage of such formulations is the reduction of the problem of chemical 
incompatibility of additives, a common occurrence in operations that use different products that have been evaluated individually (Collins et al., 2001).

\section{MATERIALS AND METHODS}

\subsection{Materials}

The crude oil was supplied by the Petrobras Research Center (CENPES), Rio de Janeiro, Brazil, with relative density, at $25^{\circ} \mathrm{C}$, of $0.88806 \mathrm{~g} / \mathrm{cm}^{3}$ and $\mathrm{API}^{\circ}$ of 26.47. The commercial ethylene-co-vinyl acetate copolymer (EVA33) was supplied by Braskem S.A., Triunfo, Brazil. The cardanol was supplied by Satya Cashew Chemical, India. The dodecylbenzenesulfonic acid (DBSA) was supplied by Sigma Aldrich, São Paulo, Brazil. The commercial asphaltene dispersant samples, INH1 and INH2, were provided by CENPES. Finally, the toluene (commercial grade) and n-heptane (P.A. 99.5\%) were supplied by Vetec Química Fina Ltd., Xerém, Brazil. All samples were used as received, except the toluene, which was distilled at $110^{\circ} \mathrm{C}$ and dried with alumina before using.

\subsection{Methods}

The efficiency of the asphaltene dispersants was determined by precipitation onset tests in a nearinfrared (NIR) spectrophotometer at $1600 \mathrm{~nm}$. With the addition of $n$-heptane the absorbance decreased because of the dilution. When the volume of $n$-heptane was enough to provoke the asphaltenes aggregation, the absorbance increased since the size of the particle was bigger. So, the asphaltenes precipitation onset was taken at the nheptane volume, in which the absorbance had its lowest value, and the result was expressed as $\mathrm{mL}$ of n-heptane/mL of oil (Carbonezi et al., 2009; Garreto et al., 2010; Garreto et al, 2013; Sousa et al., 2004). The concentrations of the dispersant were evaluated ranging from 250 to $5000 \mathrm{ppm}$. The additives were blended in the oil with the product dispersed in toluene at a concentration of $10 \mathrm{~m} / \mathrm{v} \%$. The tests were conducted with $10 \mathrm{~mL}$ of petroleum system. The flocculant solvent (n-heptane) was mixed with the petroleum system with and without additive using a chromatographic pump (flow rate $=2 \mathrm{~mL} / \mathrm{min}$ ). Plots of absorbance as a function of flocculant volume were obtained. The volume of $n$ heptane at the lowest absorbance was divided by
10 to obtain the asphaltenes precipitation onset. The error of this analysis was $\pm 0.5 \mathrm{~mL}$ of $\mathrm{n}$-heptane, so the error of asphaltenes precipitation onset is \pm $0.05 \mathrm{~mL}$ of $\mathrm{n}$-heptane $/ \mathrm{mL}$ of oil system.

The performance of the EVA33 as a wax deposition inhibitor, at concentrations of 50, 100, 500 and 1000 ppm, was evaluated by measuring the pour point and the wax appearance temperature (WAT), determined by differential scanning microcalorimetry ( $\mu D S C)$. The EVA33 was added to the oil as a solution in dry toluene at 10 $\mathrm{m} / \mathrm{v} \%$. The method of determining the pour point was adapted from the ASTM D97-93 standard, utilizing a Thermo Haake C4OP refrigerated circulator bath. First, the crude oil samples were heated to $50^{\circ} \mathrm{C}$ to eliminate any crystalline structure of the waxes. Then, they were transferred to cuvettes coupled to a thermometer and cooled. At each $2^{\circ} \mathrm{C}$ decrease in temperature the cuvettes were removed from the bath and slowly placed in an horizontal position to check whether the solution was still fluid. The temperature at which fluidity was no longer observed plus two degrees was considered the pour point. The WAT was obtained by $\mu \mathrm{DSC}$ using a SETARAM model $\mu$ DSC III microcalorimeter. First, the oil was heated in a chamber at $80^{\circ} \mathrm{C}$ for one hour to eliminate any organized paraffinic structure. Then, the samples were weighed and sealed in the stainless steel cells. At this stage, $0.400 \mathrm{~g}$ of oil were placed in sample cells and $0.3680 \mathrm{~g}$ of $\mathrm{n}$-undecane $(\mathrm{n}-\mathrm{C} 11)$ were placed in the reference cell. The analyses were carried out under dry nitrogen (N2) flow at a pressure of 1 bar, at a cooling rate of $0.6^{\circ} \mathrm{C} / \mathrm{min}$.

\section{RESULTS AND DISCUSSION}

\subsection{Evaluation of the efficiency of EVA33 as wax deposition inhibitor}

The efficiency of EVA33 as a wax deposition inhibitor was evaluated by determining the pour point (PP). This is a static test to determine the temperature at which the oil sample ceases to flow. The reduction of flow is directly associated with the reduction of kinetic energy due to the decline in temperature. Table 1 reports the pour point results for the petroleum with and without the addition of varied concentrations of EVA33. 
Table 1. Pour point of crude oil with and without adding EVA33.

\begin{tabular}{ccc}
\hline Additive & Concentration $(\mathrm{ppm})$ & Pour point $\left({ }^{\circ} \mathrm{C}\right)$ \\
\hline & - & 12 \\
EVA33 & 50 & 2 \\
& 100 & -8 \\
& 500 & $<-20^{\circ} \mathrm{C}$ \\
& 1000 & $<-20^{\circ} \mathrm{C}$ \\
\hline
\end{tabular}

The oil without EVA presented a pour point of $12^{\circ} \mathrm{C}$. EVA33 was a good pour point reducer, considering that addition of 50ppm was sufficient to lower the pour point by up to $10^{\circ} \mathrm{C}$, and with 100 ppm a reduction of $20^{\circ} \mathrm{C}$ was obtained. With EVA concentrations greater than 500ppm it was not possible to determine the exact pour point temperature of the crude oil studied due to the limited scale of the thermometer used in the experiments. The pour point value for EVA concentrations of 500 and 1000 ppm were below $20^{\circ} \mathrm{C}$. The aim of these analyses was to select concentrations of EVA33 to be utilized in preparing the combo formulations, which were 100 and 500ppm.

\subsection{Efficiency of the dispersants in stabilizing asphaltenes}

Figure 1 shows the curve of absorbance against volume of $n$-heptane for the pure oil. Since $10 \mathrm{~mL}$ of oil were used, the precipitation onset was $2.52 \mathrm{~mL}$ of $\mathrm{n}$-heptane/ $1 \mathrm{~mL}$ of oil. The higher the precipitation onset, the more stable the oil is in terms of asphaltenes precipitation.

Table 2 summarizes the onset precipitation results obtained for the pure oil and with addition of the different dispersants (DBSA, cardanol, INH1 and $\mathrm{INH}_{2}$ ) at varying concentrations. The results obtained for the DBSA indicated that it is efficient in inhibiting asphaltenes deposition at a relatively low concentration, since it retarded this precipitation in comparison to the crude oil without additive. The asphaltenes precipitation onset rose from $2.52 \mathrm{~mL}$ to $2.82 \mathrm{~mL}$ when adding only $100 p p m$ of DBSA. However, a super-dose (greater than 1000ppm) led to the inefficiency of this product, probably due to DBSA self aggregation.

Cardanol was more efficient at inhibiting asphaltenes depositions than DBSA, at all the concentrations studied. And, differently from the DBSA, cardanol was more efficient at higher concentrations, reaching its best performance at

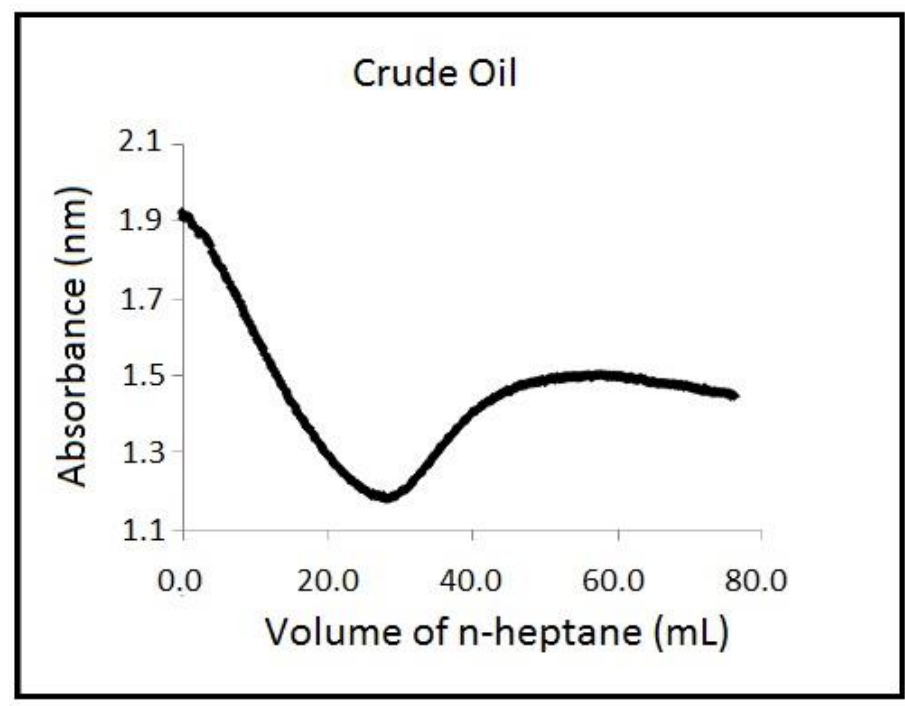

Figure 1. Absorbance against volume of $n$-heptane for the pure crude oil. 
Table 2. Precipitation onset obtained by NIR for crude with and without additive.

\begin{tabular}{ccc}
\hline Additives & $\begin{array}{c}\text { Concentration } \\
\text { (ppm) }\end{array}$ & $\begin{array}{c}\text { Precipitation onset } \\
\text { (mL of heptane/mL of oil) }\end{array}$ \\
\hline Pure crude & - & 2.52 \\
\hline \multirow{4}{*}{ DBSA } & 100 & 2.82 \\
& 500 & 2.80 \\
& 1000 & 2.80 \\
& 2000 & 2.74 \\
& 3000 & 2.50 \\
Cardanol & 5000 & 2.50 \\
& 250 & 2.90 \\
& 500 & 2.88 \\
& 2000 & 2.88 \\
& 3000 & 2.96 \\
\hline \multirow{2}{*}{ INH1 } & 5000 & 3.04 \\
& 1000 & 3.34 \\
\hline INH2 & 3000 & 2.96 \\
& 1000 & 2.74 \\
\hline
\end{tabular}

$5000 p p m$, where the precipitation onset was shifted to $3.34 \mathrm{~mL}$ of $\mathrm{n}$-heptane per $1 \mathrm{~mL}$ of oil. Some authors (Ibrahim \& Idem, 2004; Kraiwattanawong et al., 2009) have mentioned that the efficiency of asphaltenes dispersants is directly related to the acid-base interaction between the dispersants and the asphaltenes molecules.

The literature (Al-Sahhaf et al., 2002) compares resorcinol (DR), DBSA, and nonylphenol (NP) as asphaltene dispersants and observing the following order of efficiency: DR > DBSA > NP, stating that this is related to the acidity of these compounds. Resorcinol is listed as the best dispersant because its hydroxyl groups that are linked to the aromatic ring make it more acidic than the other dispersants. The chemical structure of NP is very similar to that of cardanol, and their performances were found to be very similar when evaluated in model systems (Moreira et al., 1998). Based on the performance results already reported (Moreira et al., 1998; Al-Sahhaf et al., 2002; Ibrahim \& Idem, 2004; Kraiwattanawong et al., 2009), cardanol exhibits a higher performance than DBSA due to the differences in their hydrocarbon chains, since the DSBA sulfonic group has a higher acid character than the cardanol hydroxyl group. Analyzing the hydrocarbon chains (DBSA - saturated C12 and cardanol - unsaturated C15), cardanol has a longer segment than DBSA, containing from one to three double bonds. Such characteristics make cardanol rank as the best perform as an asphaltenes deposition inhibitor, which could be related to higher hydrophobicity of the hydrocarbon chain and/or to the double bonds, exhibiting sp2 hybridization, that provides higher acidity and electronegativity to the carbon.

Both the commercial dispersants (INH1 and INH2) shifted the asphaltene precipitation onset, acting as inhibitors. At a concentration of $1000 \mathrm{ppm}$, it took 2.96 and $2.88 \mathrm{~mL}$ of $\mathrm{n}$-heptane per $1 \mathrm{~mL}$ of oil, respectively. These inhibitors exhibited lower performance at 3000ppm, which was considered a super-dosage. By comparing the results, one can observe that, at $1000 \mathrm{ppm}$, INH1 exhibited the best performance $(2.96 \mathrm{~mL}$ of $\mathrm{n}$ - 
Table 3. Asphaltenes precipitation onset of the crude with and without adding combo formulation at different concentrations.

\begin{tabular}{|c|c|c|}
\hline \multicolumn{2}{|c|}{ Formulation (ppm) } & $\begin{array}{c}\text { Asphaltenes precipitation onset } \\
\text { (mL heptane } / \mathbf{m L} \text { oil })\end{array}$ \\
\hline \multicolumn{2}{|c|}{ Pure oil } & 2.52 \\
\hline \multirow[t]{3}{*}{ DBSA 1000} & EVA 0 & 2.80 \\
\hline & EVA 100 & 2.62 \\
\hline & EVA 500 & 2.82 \\
\hline \multirow[t]{3}{*}{ DBSA 3000} & EVA 0 & 2.50 \\
\hline & EVA 100 & 2.40 \\
\hline & EVA 500 & 2.58 \\
\hline \multirow[t]{3}{*}{ Cardanol 1000} & EVA 0 & 2.88 \\
\hline & EVA 100 & 2.50 \\
\hline & EVA 500 & 2.78 \\
\hline \multirow[t]{3}{*}{ Cardanol 5000} & EVA 0 & 3.34 \\
\hline & EVA 100 & 3.16 \\
\hline & EVA 500 & 3.22 \\
\hline \multirow[t]{3}{*}{ INH1 1000} & EVA 0 & 2.96 \\
\hline & EVA 100 & 2.70 \\
\hline & EVA 500 & 2.78 \\
\hline \multirow[t]{3}{*}{ INH1 3000} & EVA 0 & 2.74 \\
\hline & EVA 100 & 2.82 \\
\hline & EVA 500 & 2.86 \\
\hline \multirow[t]{3}{*}{ INH2 1000} & EVA 0 & 2.88 \\
\hline & EVA 100 & 2.40 \\
\hline & EVA 500 & 2.58 \\
\hline \multirow[t]{3}{*}{ INH2 3000} & EVA 0 & 2.64 \\
\hline & EVA 100 & 2.74 \\
\hline & EVA 500 & 2.72 \\
\hline
\end{tabular}

heptane $/ \mathrm{mL}$ of oil), followed by equal performance of cardanol and INH2 (in both cases $2.88 \mathrm{~mL}$ of $\mathrm{n}$ heptane/mL of oil). However, the greatest shift in the precipitation onset, corresponding to the best performance in stabilizing asphaltenes, was obtained at a concentration of $5000 \mathrm{ppm}$ of cardanol.

\subsection{Evaluation of the efficiency of the} combo formulations in inhibiting deposition of asphaltenes and waxes

The concentrations of each additive to prepare the combined formulations composed of two products (EVA and an asphaltenes dispersant) were selected based on the results for pour point and precipitation onset of waxes. The EVA concentrations chosen to prepare the formulations were 100 and 500ppm, at which the oil had presented pour points of $-8^{\circ} \mathrm{C}$ and $<-20^{\circ} \mathrm{C}$, respectively. The asphaltenes dispersants were used at concentrations of 1000 and 3000ppm, except for the cardanol, which had concentrations of 1000 and 5000ppm. For all these formulations, the pour point values remained the same as those obtained with pure EVA33. This result indicates that the asphaltenes dispersants employed did not have any interaction with the waxes, so they did not affect (negatively or positively) the inhibition of wax deposition.

The same behavior was not observed for the influence of EVA33 on the performance of the 


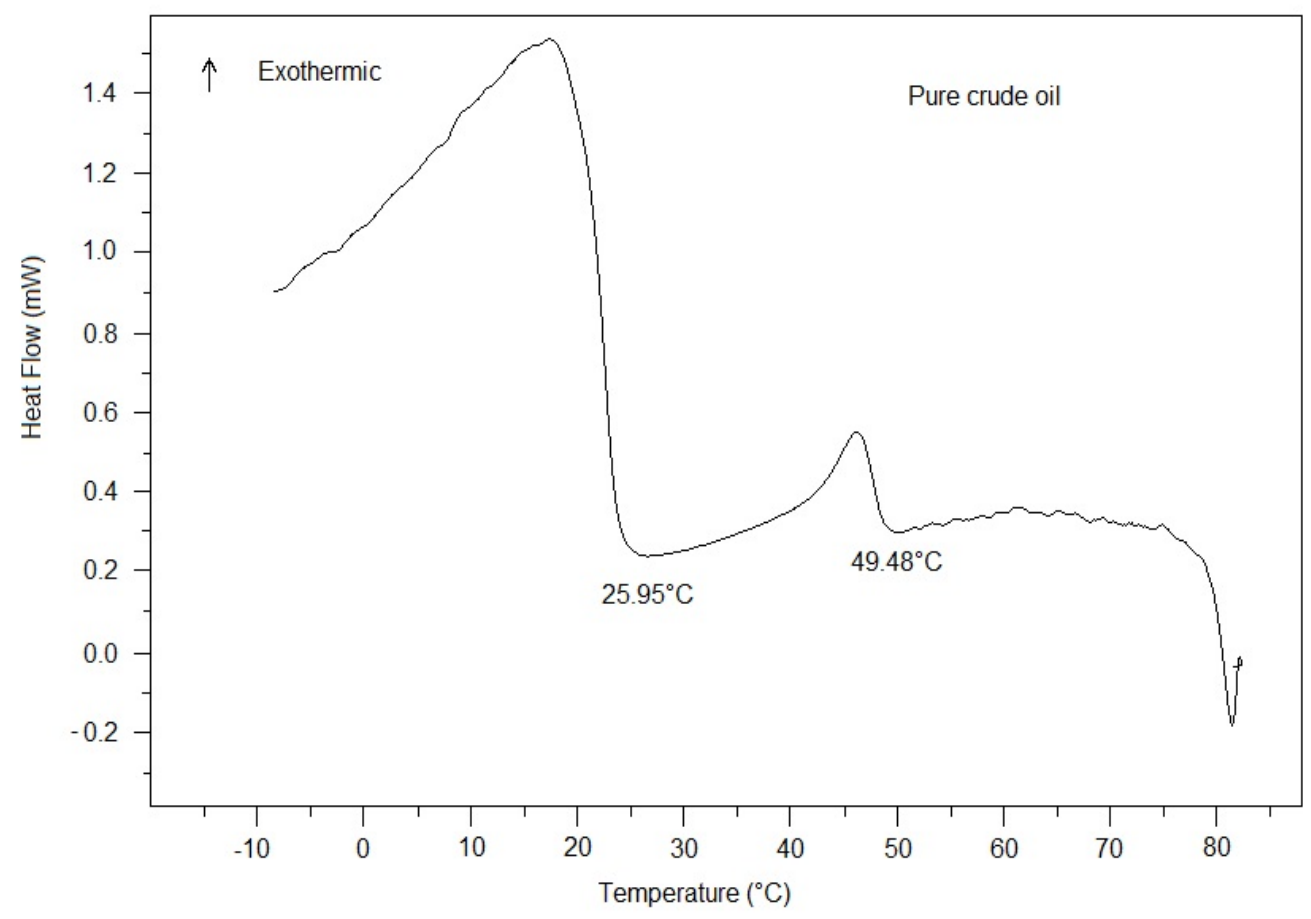

Figure 2. Heat flow against temperature of the crude oil obtained by microcalorimetry.

asphaltenes dispersants. The precipitation onset results for all the formulations prepared, presented in Table 3, show that in some cases the EVA33 shifted the onset to lower values, thus, reducing the dispersant's efficiency. For example, for INH2 at the concentration of $1000 \mathrm{ppm}$, which before the addition of EVA33 presented a precipitation onset of $2.88 \mathrm{~mL}$ of $\mathrm{n}$-heptane $/ \mathrm{mL}$ of oil, the amounts of $\mathrm{n}$-heptane fell to 2.40 and $2.58 \mathrm{~mL}$ at EVA33 concentrations of 100 and $500 \mathrm{ppm}$, respectively. This same behavior was observed for all the formulations except for INH1 and INH2 at $3000 \mathrm{ppm}$, which presented a slight increase in the asphaltenes precipitation onset when used together with EVA33 at the two concentrations tested (100 and 500ppm). In all cases of a negative influence of EVA33 on the stabilization of asphaltenes, the lowest EVA33 concentration (100ppm) had the mildest negative effect, indicating the EVA33 concentration of 500ppm in the formulation as being the most adequate for inhibiting waxes and asphaltenes deposition. Formulations containing 5000ppm of cardanol reduced the asphaltenes precipitation onset from $3.34 \mathrm{~mL}$ of heptane $/ \mathrm{mL}$ of oil to 3.16 and $3.22 \mathrm{~mL}$ of $\mathrm{n}$-heptane/mL of oil, when used in the formulations containing, respectively, 100 and 500ppm of EVA33. However, these formulations still presented the best performances. Moreover, the cardanol is a natural product extracted from cashew nutshells, a renewable source.

\subsection{Determination of the wax appearance temperature (WAT) of the combo formulations by microcalorimetry}

Differential scanning microcalorimetry ( $\mu \mathrm{DSC})$ is widely used to measure the wax appearance temperature (WAT) (Vieira et al., 2010; Bai \& Zhang, 2013). The basic principle of this technique is the detection of the latent heat of solidification released during the crystallization process of the paraffin molecules present in crude oil, by cooling the samples. Figure 2 shows the curve obtained for the pure crude oil, where two events can be observed: the onset of each event was detected at $49.48^{\circ} \mathrm{C}$ and $25.95^{\circ} \mathrm{C}$.

Table 4 summarizes the results obtained for all the formulations studied. As reported in the literature, EVA does not inhibit the formation of wax crystals (Machado et al., 2001). Instead it modifies the crystalline morphology, so the process of reducing the pour point is not necessarily 
Table 4. Results obtained from microcalorimetry for the crude oil with and without adding "combo" formulation.

\begin{tabular}{cccc}
\hline \multicolumn{2}{c}{ Formulation (ppm) } & $\mathbf{1}^{\circ}$ Crystallization event (WAT) & $\mathbf{2}^{\circ}$ Crystallization event \\
\hline \multicolumn{2}{c}{ Pure oil } & 49.48 & 25.95 \\
\hline DBSA 1000 & EVA 100 & 46.49 & 25.01 \\
& EVA 500 & 46.70 & 26.10 \\
\hline DBSA 3000 & EVA 100 & 46.48 & 25.01 \\
& EVA 500 & 49.29 & 25.65 \\
\hline Cardanol 1000 & EVA 100 & 46.65 & 25.53 \\
& EVA 500 & 47.60 & 25.18 \\
\hline Cardanol 5000 & EVA 100 & 48.08 & 26.01 \\
& EVA 500 & 47.01 & 25.86 \\
\hline \multirow{2}{*}{ INH1 1000 } & EVA 100 & 46.40 & 25.10 \\
& EVA 500 & 47.50 & 25.45 \\
\hline \multirow{2}{*}{ INH1 3000 } & EVA 100 & 46.20 & 26.05 \\
& EVA 500 & 48.10 & 25.36 \\
\hline INH2 1000 & EVA 100 & 46.55 & 25.10 \\
& EVA 500 & 46.60 & 25.50 \\
\hline INH2 3000 & EVA 100 & 48.03 & 25.35 \\
& EVA 500 & 47.50 & 25.45 \\
\hline
\end{tabular}

associated with a variation in the system's WAT. The objective of the $\mu \mathrm{DSC}$ analyses was to check whether the asphaltenes dispersants, mixed with EVA33, affected the WAT. The results showed that the crude oil used has two exothermic peaks, related to two crystallization events, as observed in previous studies (Singh et al., 2000; Soni et al., 2005). The WAT was taken as the onset temperature of the first crystallization event during cooling. The results presented in Table 4 indicate that in general the formulations tested did not cause a significant variation of the oil's WAT. Concerning to the 2nd event, the results were essentially the same since the error of these analyses was $\pm 0.5^{\circ} \mathrm{C}$. These results corroborate the observation that the asphaltenes dispersants did not affect the crystallization of the paraffin molecules in the petroleum.

\section{CONCLUSIONS}

The EVA33 performed well in reducing the pour point of the crude oil studied, since at concentrations of around $50 \mathrm{ppm}$ it reduced the pour point from $12^{\circ} \mathrm{C}$ to $2^{\circ} \mathrm{C}$. An even better performance was obtained with the concentration of 500ppm, when the pour point declined to a temperature below $-20^{\circ} \mathrm{C}$.

In relation to the asphaltene dispersants, cardanol performed better than the dodecylbenzenesulfonic acid and the two commercial dispersants, shifting the asphaltene precipitation onset from $2.52 \mathrm{~mL}$ to $3.34 \mathrm{~mL}$ of $\mathrm{n}$ heptane $/ \mathrm{mL}$ of oil with $5000 \mathrm{ppm}$ of cardanol. With respect to the combo formulations, the asphaltene dispersants did not influence the performance of the EVA33 as a reducer of the pour point, and the WAT values confirmed this behavior. The EVA33, in turn, had little influence on the performance of the asphaltene dispersants in shifting the precipitation onset, with this influence being mildest at the EVA33 concentrations of 500ppm than at $100 \mathrm{ppm}$. The crude oil mixed with the formulations containing $5000 \mathrm{ppm}$ of cardanol/100 ppm of EVA33 and 5000 ppm of cardanol/500 ppm of EVA 33 performed the best, with asphaltene precipitation onset values of 3.16 and $3.22 \mathrm{~mL}$ of $\mathrm{n}$ heptane/mL of oil, respectively. Additionally, cardanol has the advantage of being a product that comes from a renewable source.

This work evidences the potential of developing multifunctional formulations, which can lead to 
lower costs and greater facility in applying products in the petroleum industry. Moreover, novel formulations can prevent problems related to the incompatibility of additives.

\section{ACKNOWLEDGMENTS}

The authors thank CNPq, CAPES, Petrobras, and ANP for funding.

\section{REFERENCES}

Aiyejina, A.; Chakrabarti, D. P.; Pilgrim, A.; Sastry, M. K. S. Wax formation in oil pipelines: A critical review. International Journal of Multiphase Flow, v. 37, p. 671-694, 2011.

http://dx.doi.org/10.1016/j.ijmultiphaseflow.2011.02.007

AL-sahhaf, T. A.; Fahim, M. A.; Elkilane, A. S. Retardation of asphaltene precipitation by addition of toluene, resins, deasphalted oil and surfactants. Fluid Phase Equilibria, v. 194-197, p. 1045-1057, 2002.

http://dx.doi.org/10.1016/S0378-3812(01)00702-6

American Society for testing and materialsASTM D-97-93 (66) Standard test method pour point of petroleum oils, Reprint, 1971.

Araújo, J. C.D.; Lucena, S.; Silva, J. C. S.; Silva, L. M. X.; Kyotoku, G. B. C. Effect of thermodynamical model for paraffin deposition in the paraffinic oil laminar flow through circular ducts. Brazilian Journal of Petroleum and Gas, v. 2, p. 55-62, 2008.

Bai, C.; Zhang, J. Thermal, macroscopic, and microscopic characteristics of wax deposits in field pipelines. Energy \& Fuels, v. 27, 752-759, 2013. http://dx.doi.org/10.1021/ef3017877

Carbonezi, C. A.; Almeida, L. C.; Araujo, B.; Lucas, E. F.; González, G. Solution behavior of naphthenic acids and its effects on the asphaltenes precipitation onset. Energy \& Fuels, v. 23, 12491252, 2009. http://dx.doi.org/10.1021/ef800683c

Castro, L. V.; Vazquez, F. Copolymers as flow improvers for mexican crude oils. Energy \& Fuels, v., 22, p. 4006-4011, 2008.

http://dx.doi.org/10.1021/ef800448a
Chang, C; Fogler, H.S. Stabilization of asphaltenes in aliphatic solvents using alkylbenzene-derivated 1 . Effect of the chemical structure of amphiphiles on asphaltenes stabilization. Langmuir, v. 10, p. 1749-1757, 1994. http://dx.doi.org/10.1021/la00018a022

Chen, W.; Zhao, Z.; Yin, C. The interaction of waxes with pour point depressants. Fuel, v. 89, p. 1127-1132, 2010.

http://dx.doi.org/10.1016/j.fuel.2009.12.005

Chouparova, E.; Lanzirotti, A.; Feng, H.; Jones, K. W.; Marinkovic, N.; Whitson, C.; Philp, P. Characterization of petroleum deposits formed in a producing well by synchrotron radiation-based microanalyses. Energy \& Fuels, v. 18, p.1199-1212, 2004. http://dx.doi.org/10.1021/ef030108a

Collins, I. R.; Hedges, B.; Harris, L.M.; Fan, J. C.; Fan, L. D. G. The development of a novel environmentally friendly dual functional corrosion and scale inhibitor. Society of Petroleum Engineers, SPE 65005, 2001.

Embrey, M.; Larke, J. Paraffin-plug remediation in deep water wells via capillary tubing: a cost effective alternative. Journal Society of Petroleum Engineers. (SPE) 135136, p. 1-12, 2010.

Fan, Y.; Simon, S.; Sjöblom, J. Interfacial shear rheology of asphaltenes at oil-water interface and its relation to emulsion stability: Influence of concentration, solvent aromaticity and nonionic surfactant. Colloids and Surfaces A: Physicochem. Eng. Aspects, v. 366, p. 120-128, 2010. http://dx.doi.org/10.1016/i.colsurfa.2010.05.034

Garreto, M. S. E.; Gonzalez, G.; Ramos, A. C.; Lucas, E. F. Looking for a model solvent to disperse asphaltenes. Chemistry \& Chemical Technology, v. 4, p. 317-323, 2010.

Garreto, M. S. E.; Mansur, C. R. E.; Lucas, E. F. A model system to assess the phase behavior of asphaltenes in crude oil. Fuel, v. 113, p. 318-322, 2013. http://dx.doi.org/10.1016/j.fuel.2013.05.097

Gentili, D. O.; Khalil, C. N.; Rocha, N. O.; Lucas, E. F. Evaluation of polymeric phosphoric ester-based additives as wax deposition inhibitors. Society of Petroleum Engineers (SPE International), SPE 94821, 2005. 
Gonzales, P.; Passade-boupat, N.; Bascoul, P.; Baraka-Lokmane, S.; Hurtevent, C. Selection of antiscale and anti-corrosion products: How to avoid interactions? Society of Petroleum Engineers, 2012.

Hernández-Altamirano, R.; Mena-Cervantes, V. Y.; Chávez-Miyauchi, T. E.; Nieto-Álvarez, D. A.; Domínguez-Aguilar,M. A.; Zamudio-Rivera, L. S.; Barba, V.; Fernández-Perrino, F. J.; Pérez-Miranda, S.; Beltrán, H. I. New bis-di-organotin compounds derived from aminoacid-imine hexadentate ligands. Multifunctional evaluation as corrosion inhibitors, antibacterials and asphaltene dispersants/inhibitors. Polyhedron, v. 52, p. 301307, 2013.

http://dx.doi.org/10.1016/j.poly.2012.09.022

Honse, S. O.; Ferreira, S. R.; Mansur, C. R. E.; Gonzalez, G.; Lucas, E. F. Separation and characterization of asphaltenic subfractions. Quimica Nova, v. 35, p. 1991-1994, 2012. http://dx.doi.org/10.1590/S0100-40422012001000019

Hutter, J. L.; Hudson, S.; Smith, C.; Tetervak, A.; Zhang, J. Banded crystallization of tricosane in the presence of kinetic inhibitors during directional solidification, Journal of Crystal Growth, v. 273, p. 292-308, 2004.

http://dx.doi.org/10.1016/j.jcrysgro.2004.08.017

Ibrahim, H. H.; Idem, R. O. CO2-miscible flooding for three saskatchewan crude oils: interrelationships between asphaltene precipitation inhibitor effectiveness, asphaltenes characteristics, and precipitation behavior. Energy \& Fuels, v. 18, p. 743-754, 2004.

http://dx.doi.org/10.1021/ef0340458

Jackson, M. The use injection of multifunctional chemical via gas lift increase oil production. Society of Petroleum Engineers, SPE 108780, 2007.

Júnior, W. B; Silva, D. N.; Souza, C. P.; Oliveira, H. N. M.; Moraes, J. E. F.; Filho, O. C. Phase changes of petroleum mixtures by monitoring temperature and conductivity for paraffin formation. Brazilian Journal of Petroleum and Gas, v.1, p. 34-44, 2007.
Juyal, P.; Yen, A. T.; Rodgers, R. P.; Allenson, S.; Wang, J.; Creek, J. Compositional Variations between precipitated and organic solid deposition control (OSDC) asphaltenes and the effect of inhibitors on deposition by electrospray ionization Fourier transform ion cyclotron resonance (FT-ICR) mass spectrometry. Energy \& Fuels, v. 24, p. 23102326, 2010. http://dx.doi.org/10.1021/ef900959r

Kane, M.; Djabourov, M.; Volle, J. L.; Lechaire, J. P.; Frebourg, G. Morphology of paraffin crystals in waxy crude oils cooled in quiescent conditions and under flow. Fuel, v. 82, p. 127-135, 2003. http://dx.doi.org/10.1016/50016-2361(02)00222-3

Kraiwattanawong, K.; Fogler, H. S.; Gharfeh, S. G.; Singh, P.; Thomason, W. H.; Chavadej, S. Effect of asphaltene dispersants on aggregate size distribution and growth. Energy \& Fuels, v. 23, p. 1575-1582, 2009.

http://dx.doi.org/10.1021/ef800706c

Lima, A. F.; Mansur, C. R. E.; Lucas, E. F.; Gonzalez, G. Polycardanol or sulfonated polystyrene as flocculants for asphaltene dispersions. Energy \& Fuels, v. 24, p. 2369-2375, 2010. http://dx.doi.org/10.1021/ef901031h

Lucas, E. F.; Mansur, C. R. E.; Spinelli, L.; Queirós, Y. G. C. Polymer science applied to petroleum production. Pure and Applied Chemistry, v. 81, n. 3, p. 473-494, 2009. http://dx.doi.org/10.1351/PAC-CON-08-07-21

Machado, A. L. C.; Lucas, E. F.; González, G. Poly(ethylene-co-vinyl acetate) (EVA) as wax inhibitor of a brazilian crude oil: oil viscosity, pour point and phase behavior of organic solutions, Journal of Petroleum Science \& Engineering, v.32, p. 159-165, 2001. http://dx.doi.org/10.1016/S09204105(01)00158-9

Mansur, C. R. E.; Melo, A. R.; Lucas, E. F. Determination of asphaltenes particles size: Influence of flocculant, additive and temperature. Energy \& Fuels, v. 26, p. 4988-4994, 2012. http://dx.doi.org/10.1021/ef300365x 
Mansur, C. R. E.; Lima, A. F.; Spinelli, L. S.; González, G.; Lucas, E. F. Is there any relation between the solubility of a polymeric additive and its performance as a pour point reducer? Macromolecular Symposia, 2006. http://dx.doi.org/10.1002/masy.200651335

Marie, E.; Chevalier, Y.; Eydoux, F.; Germanaud, L.; Flores P. Control of $n$-alkanes crystallization by ethylene-vinyl acetate copolymers. Journal Colloid \& Interface Science, v. 290, p. 406-418, 2005. http://dx.doi.org/10.1016/i.jcis.2005.04.054

Mcnaughtan, D.; Winning, I. G.; Sim, M. The evaluation of a new environmentally friendly combined products for application in the North Sea for effective scale and corrosion control. Society of Petroleum Engineers, SPE 90444, 2004.

Moreira, L.F.B.; González, G.; Lucas, E.F. Estudo da Interatividade entre Macromoléculas Asfaltênicas e Compostos Estabilizantes: LCC e Cardanol. Polímeros: Ciência e Tecnologia, jul/set, p. 46-54, 1998.

Mullis, O. C. Petroleomics and structurefunction relations of crude oils and asphaltenes in asphaltenes, heavy oils, and petroleomics, Springer, New York, 2007, cap.1 (in English).

Oliveira, G. E.; Mansur, C. R. E.; Lucas, E. F.; Gonzales, G.; Souza, W. F. The effect of asphaltenes, naphthenic acids, and polymeric inhibitor on the pour point of paraffins solutions. Journal of Dispersion Science and Technology, $v$. 28, p. 1-8, 2007.

http://dx.doi.org/10.1080/01932690601107526

Piroozan, Z.; Kharrat, R.; Emamzadeh, A. Study of asphaltene precipitation-deposition due to pressure depletion. Brazilian Journal of Petroleum and Gas, v.4, p. 71-81, 2010.

Silva, C. X.; Álvares, D. R. S.; Lucas, E. F. New Additives for the pour point reduction of petroleum middle distillates. Energy \& Fuels, v. 18, p. 599-604, 2004.

http://dx.doi.org/10.1021/ef030132o

Singh, P.; Venkatesan, R.; Fogler, H. S.; Nagarajan, N. Formation and aging of incipient thin film wax-oil gels. AIChE Journal:Materials, interfaces, and electrochemical phenomena, v. 46, p. 1059-1074, 2000.
Smith, D. F.; Klein, G. C.; Yen, A. T.; Squicciarini, M. P.; Rodgers, R. P.; Marshall, A. G. Crude Oil Polar Chemical Composition Derived from FT-ICR Mass Spectrometry Accounts for Asphaltene Inhibitor Specificity. Energy \& Fuels, v.22, p. 3112-3117, 2008. http://dx.doi.org/10.1021/ef800036a

Soni, H. P.; Bharambe, D. P.; Nagar, A.; Kiranbala. Synthesis of chemical additives and their effect on Akholjuni crude oil (Gujarat, India). Indian Journal of Chemical Technology, v.12, p. 55-61, 2005.

Soni, H. P.; Kiranbala; Agrawal, K. S.; Nagar, A.; Bharambe, D. P. Designing maleic anhydride- $\alpha-$ olifin copolymeric combs as wax crystal growth nucleators. Fuel Processing Technology, v. 91, p. 997-1004, 2010.

http://dx.doi.org/10.1016/j.fuproc.2010.02.019

Sousa, M. A.; Oliveira, G. E.; Lucas, E. F.; González, G. The onset of precipitation of asphaltenes in solvents of different solubility parameters. Progress in Colloid and Polymer Science, v. 128, p. 283-287, 2004.

Terry, A. E.; Hobbs, J. K.; Organ, S. J.; Barham, P. J. In Situ Synchrontron Study of the solution crystallization of ultralong alkanes from dilute solution. Polymer, v. 44, p. 3001-3008, 2003. http://dx.doi.org/10.1016/S0032-3861(03)00211-8

Vargas, F.M.; Gonzales, D. L.; Creek, J. L.; Wang, J.; Buckley, J.; Hirasaki, G. J.; Chapman, W. G. Development of a general method for modeling asphaltene stability. Energy \& Fuels, v. 23, p. 11471154, 2009. http://dx.doi.org/10.1021/ef800666j

Vieira, L. C.; Buchuid, M. B; Lucas, E. F. Effect of pressure on the performance of poly(ethylene-vinyl acetate) as was deposition inhibitors by calorimetric method. Journal of Applied Polymer Science, v. 126, p. 143-149, 2012. http://dx.doi.org/10.1002/app.35050

Vieira, L. C.; Buchuid, M. B; Lucas, E. F. The effect of pressure on the crystallization of crude oil waxes. I. Selection of test conditions by microcalorimetry. Energy \& Fuels, v.24, p.22082212, 2010. http://dx.doi.org/10.1021/ef900711d 
Vieira, L. C.; Buchuid, M. B; Lucas, E. F. The effect of pressure on the crystallization of crude oil waxes. II. Evaluation of crude oils and condensate. Energy \& Fuels, v. 24, p. 2213-2220, 2010. http://dx.doi.org/10.1021/ef900761t

Visintin, R. F. G.; Lockhart, T. P.; Lapasin, R.; D'Antona, P. Structure of waxy crude oil emulsion gels. Journal of Non-Newtonian Fluid Mechanics, v. 149, p. 34-39, 2008.

http://dx.doi.org/10.1016/j.jnnfm.2007.07.008
Zhang, X. X.; Fan, Y. F.; Tao, X. M.; Yick, K. L. Crystallizations and prevention of supercooling of microencapsulated n-alkanes, Journal of Colloid and Interface Science, v. 281, p. 299-306, 2005. http://dx.doi.org/10.1016/j.jcis.2004.08.046 